\title{
Article \\ Does Financial Development Drive Private Investment in Ghana?
}

\author{
Daniel Sakyi ${ }^{1}$, Micheal Kofi Boachie ${ }^{2}$ and Mustapha Immurana ${ }^{3, *}$ \\ 1 Department of Economics, Kwame Nkrumah University of Science and Technology, Kumasi, PMB, Ghana; \\ dsakyi.cass@knust.edu.gh \\ 2 Department of Economics, Annamalai University, Annamalai Nagar, 608002, Tamil Nadu, India; \\ mkboachie@gmail.com \\ 3 Department of Economics, Mangalore University, Mangaluru, 574119, India \\ * Correspondence: mustaphaimmurana@gmail.com; Tel.: +91-974-079-0500
}

Academic Editor: Helmi Hamdi

Received: 5 May 2016; Accepted: 31 October 2016; Published: 1 December 2016

\begin{abstract}
There is ample evidence from economic growth literature that investment accelerates economic growth and development of developing countries, of which Ghana is not an exception. Based on this, recent growth and development policies in Ghana have focused more on encouraging private sector investment through the development of the financial sector. This paper investigates the short- and long-run impact of financial development on private investment in Ghana for the years 1970-2014. Additionally, to find out whether the measurement of financial development matters for private investment, several indicators of financial development are used. The results, based on the ARDL bounds testing approach to cointegration, suggest that financial development has not been a key driver of private investment in the long run, while, in the short run, the effect of financial development on private investment depends on how financial development is measured. Given these results, policy makers should be circumspect regarding the choice of financial development indicator used as a policy instrument in the design and implementation of private investment policies for Ghana.
\end{abstract}

Keywords: financial development; private investment; ARDL; Ghana

JEL Classifications: C13; C32; E22; E44

\section{Introduction}

Investment has been shown to have a positive significant impact on economic growth (e.g., Khan and Reinhart, 1990 [1]; Hoeffler, 2002 [2]; and Frimpong and Adam, 2010 [3]). Specifically, proponents argue that private investment has a greater impact on economic growth because of its relative efficiency and job creation potential (Coutinho and Gallo, 1991 [4]; Serven and Solimano, 1990 [5]). In view of this, attention has recently been put on building the private sector in developing countries to help reap these benefits. It is therefore not surprising that developed countries and development-oriented institutions such as the International Financial Corporation (IFC) continue to formulate and/or support policies to promote private sector-led investment in the development agenda. For example, the African Enterprise Fund and the African Growth Fund were established by the IFC and the United States, respectively, to help boost private investment (Ouattara, 2004 [6]).

On the part of developing country governments, the strategies have included, but not limited to, financial sector reforms, trade liberalisation, subsidies, and public-private-partnerships to encourage private investment. Specifically, on financial sector reforms or financial development (FD), there has been a long-held perception that a properly working financial system creates a better means of 
allocating resources within an economy. This is so because a well-developed financial system reallocates resources from low productive to high productive sectors; and this plays an important role in total factor productivity growth through investment (Huang, 2010 [7]). For example, McKinnon (1973) [8], Shaw (1973) [9] and Singh (1997) [10] view financial development and financial deepening as an important source of savings mobilisation, credit allocation, capital productivity, and investment.

In spite of the arguments raised about the positive impact of financial development on investment, especially private investment, van Wijnbergen (1983) [11], Taylor (1983) [12] and Lensink (1996) [13] have maintained that financial development does not really enhance credit allocation in most developing nations. They postulate that financial development may shift funds from the informal financial sector-which is the major financier of most investment projects in Sub-Saharan African (SSA) countries - to formal markets, thereby resulting in low investment efficiency. To buttress the above argument, Burkett and Dutt (1991) [14] postulate that the rise in interest rate, following financial liberalisation, may raise the marginal propensity to save (MPS) and, consequently, end up lowering investment in a financially opened economy. This stems from the fact that higher MPS can reduce aggregate demand and output, hence lowering investment.

In the early 1980s, Ghana (with many other developing countries) began liberalising the economy following the implementation of the Structural Adjustment and the Economic Recovery Programmes suggested by the IMF/World Bank. Major reforms within the financial sector were embarked upon to lessen government involvement in financial markets and address the deficiencies of the financial system. The reforms, which have been well documented by, for instance, Aryeetey et al. (2000) [15] and Bawumia (2010) [16], were expected to: enhance the flow of funds via a well-structured financial system; attain some stability with regards to interest rates on borrowing to help reduce uncertainties; ameliorate the mechanism of self-finance in enterprises and households; strengthen the capital markets, money markets and intermediation by insurance companies and trusts. The aim was to enhance and speed up economic growth by using investment as one of the major conveyance processes. The expectation was that the freed interest rates would enhance savings and increase deposits in banks, and make funds available to be channelled into capital formation. Furthermore, there seems to be less progress in private sector involvement in the Ghanaian economy despite development in the financial system (Asare, 2013 [17]). Indeed, economic growth within the last few decades has been impressive, but the rate of savings and investment necessary to achieve sustained growth remains significantly lower, thereby presenting a threat to job creation and poverty reduction (Asare, 2013 [17]; Naa-Idar et al. 2012 [18]; Asante, 2000 [19]).

It is not surprising that the impact of financial development on private investment in Ghana remains inconclusive. Additionally, some previous studies on the determinants of investment and/or private investment in Ghana failed to capture the effects of financial development (see e.g., Ibrahim, 2000 [20]). For studies that capture the impact of financial development, only a few measures of FD have been used (see Asante, 2000 [19]; Akpalu, 2002 [21]; Frimpong and Marbuah, 2010 [22]; Frimpong and Adam, 2010 [3]; Asare, 2013 [17]; and Eshun et al., 2014 [23]) $)^{1}$. In this study, we revisit the impact of financial development on private investment in Ghana. To do so in a comprehensive way, we use five indicators, namely private sector credit by deposit money banks to GDP, financial system deposit to GDP, broad money supply to GDP, deposit money bank assets to GDP, and a composite index constructed by principal component analysis. The rest of the paper is structured as follows: the next section reviews related literature while Section 3 provides our methodological framework. We present and discuss our empirical results in Section 4 , and conclude the study in the last section.

1 Asante (2000) [19], Akpalu (2002) [21], Frimpong and Marbuah (2010) [22] and Asare (2013) [17] use only one indicator of financial development, i.e., credit to the private sector (as percent of GDP). Frimpong and Adam (2010) [3] use three measures of financial development, i.e., credit to private sector, bank liquid reserves to bank assets ratio and liquid liability to GDP ratio. Eshun et al. (2014) [23] include credit to private sector and money supply as measures of financial development. 


\section{Financial Development (FD) and Private Investment: A Brief Review}

Many works have been done to explain how investment behaves (see e.g., Keynes, 1936 [24]; Tobin, 1969 [25]; Jorgenson, 1971 [26]; and McKinnon, 1973 [8]). In traditional economic theory, investment is largely determined by the cost of borrowing, i.e., interest rate. When this cost is low, investors or businesses undertake more investment projects. However, neoclassical economists believe that a rise in the collection of real money balances in a portfolio resulting from a fall in the real benefit on physical capital relative to the benefit on money (cash) may also have the effect of decreasing investment. Thus, investment and money balances are perfect substitutes. Hence, investment is negatively affected by inflation since a persistent rise in prices reduces the value and benefit of real money balances.

Uncertainty has become more apparent in the theory of investment due to its irreversible nature (Pindyck, 1991 [27]). An increasingly developing literature has moved the crux of the analysis to the adjustment costs caused by acquiring and installing capital stressing the permanent nature of most investment projects (Dixit and Pindyck, 1994 [28]). The rationale is that since most capital goods are usually firm-specific and have less value when resold, negative investment is rather costly compared to investing positively. Thus, the worth of the capital project must be greater than its cost of purchasing and installing by an amount, which is the same as the worth of keeping the investment option awake. These uncertainties resulting from financial markets in the form of interest rate volatility, inflation, irreversible nature of investments, and political structures of the country inter alia also have specific implications for private sector investment decisions.

Financial development (FD) relates to "the factors, policies, and institutions that lead to effective financial intermediation and markets, as well as deep and broad access to capital and financial services" (WEF, 2012) [29]. That is, financial development relates to the perfections in financial functions such as producing information about viable investments opportunities and allocating capital to such viable opportunities, management of risk, savings mobilization, and easing exchange activities within the economy. According to Greenwood and Jovanovich (1990) [30], financial institutions are very influential in investment because of their ability to obtain and assess data concerning the level of technology and to divert investment funds available into ventures that give the highest rewards. Thus, with the existence of information, financial systems play an efficient role in investment decisions since both borrowers and investors are provided with information on expected payments based on the existing nation-wide interest rate. Financial development includes policies targeting the liberalization of financially subjugated nations from the consequences of financial policies that limit growth (Fowowe, 2011 [31]). In this way, developments in the financial sector usually consist of policies that promote effective financial intermediation and markets, prompting the ease with which exchange takes place in the economy and ensuring access to capital and other financial services in an easy manner. This promotes savings and generates higher investment. Financial repression may synthetically reduce interest rates. However, since funds available for investment are shared on the basis of on non-market measures such as family relations, friendship, and political influence, such measures usually lead to less investment and imprudent sharing of funds among investment activities (Fowowe, 2011 [31]). Thus, sound and resilient macroeconomic environment is crucial in persuading private sector players to undertake investment projects. ${ }^{2}$

Other endogenous finance-growth models (e.g., Diamond, 1984 [32]; Diamond and Dybvig, 1983 [33]; Bencivenga and Smith, 1991 [34]; and Greenwood and Smith, 1997 [35]) suggest that financial markets and institutions go to stimulate portfolio allocation towards productive investment by lessening liquidity risks, providing liquidity to savers, applying corporate discipline and decreasing the cost of resource agglomeration. Thus, a well-functioning financial system has potential effects on investment decisions, particularly for the private sector players. However, dissenting views have been

2 See the Financial Development Report, 2012 [29], published by the World Economic Forum for full details on composition (or pillars) of financial development. 
advanced by Taylor (1983) [12], Burkett and Dutt (1991) [14], and Lensink (1996) [13] regarding the positive aspects of financial development and investment, particularly for developing countries where private investment is basically the demand for capital agglomeration by owners of capital such that these kinds of savings fall when interest rates increase (Khatkhate, 1988 [36]). Therefore, theoretically, the effect of financial development on private investment is therefore contentious.

Empirically, much literature exists on this theme. The conclusions emanating from most of these studies suggest that the effect of financial development on private investment is elusive depending on how financial development is measured. For instance, Mbanga (2002) [37] has reported from a 1970-1999 dataset on Cameroon that besides public investment, credit to the private sector is important for private investment to thrive. Using four different indicators, Ucan and Ozturk (2011) [38] showed that financial development was a significant driver of private investment in Turkey during 1970-2009. Earlier findings from Oshikoya (1992) [39] in Kenya also suggest that financial developments emanating from interest rate deregulation highly influenced private investment between 1970 and 1989. Repressive financial policies usually do not induce private sector participation in India (Ang, 2009 [40]). In Ghana, Asante (2000) [19]; Asare, (2013) [17]; Frimpong and Marbuah (2010) [22]; Eshun et al. 2014) [23], among others, have attempted to capture the effects of financial development on private investment. Evidence from some of these studies suggests that financial development is one of the key variables promoting private investment.

\section{Methodological Framework}

\subsection{Proxy Measures and Data}

To establish the impact of financial development on private sector investment, a private investment model is set up with the annual private investment expenditure (share of GDP) as the dependent variable. The independent variables include a variable representing financial development and other variables controlling for other factors. The indicators of financial development are private sector credit by deposit money banks to GDP (PSC), financial system deposit to GDP (FDG), broad money supply to GDP (BM), deposit money bank assets to GDP (DMG), and an index constructed by principal component analysis (FDPCA) from the four indicators in which the first component used explained $91.47 \%$ of the variations in the data. First, private-sector credit by deposit money banks to GDP reflects, to a greater extent, the efficacy of financial institutions in giving loans to the private sector. A rise in private sector credit is seen as a positive development due to its efficient investment decisions (Coutinho and Gallo, 1991 [4]; Serven and Solimano, 1990 [5]; and Khan, 2008 [41]). It also measures the importance of the financial sector in allocating credit to the private sector and has been used in King and Levine (1993a) [42], Moshi and Kilindo (1999) [43], Levine et al. (2000) [44], Frimpong and Adam (2010) [3] and Eshun et al. (2014) [23] as a measure of financial development. Deposit money bank assets to GDP represents the claims on the domestic real nonfinancial sector by deposit money banks as a share of GDP, whereas financial system deposits to GDP consist of all demand, time and saving deposits in deposit money banks and other financial institutions as a share of GDP. These ratios also represent depth of financial services provided by the banking sector in the economy. Broad money supply to GDP measures the level of monetization in the economy and serves as a key economic indicator in forecasting inflation and the size of the financial sector (Lenka, 2015 [45]; Ucan and Ozturk, 2011 [38]; Demetriades and Hussein 1996 [46]). Our control variables are real interest rate (R), public sector investment (PUINV), real GDP per capita $(\mathrm{Y})$, real exchange rate (RER), and trade openness (OPEN). The arguments advanced in favour or otherwise of these variables in relation to private investment are articulated in the literature (see e.g., King and Levine, 1993a [42]; 1993b [47]; Fry, 1997 [48]; World Bank, 1989 [49]; Serven, 2002 [50]).

A variety of data sources (World Bank's Financial Development and Structure, and World Development Indicators databases, IMF International Financial Statistics (IFS), and Bank of Ghana 
reports and bulletins) were used to obtain data. The data cover the period 1970 to 2014. Except real per capita income, all variables are in ratios.

\subsection{Estimation Strategy}

The Private Investment Model

Based on the extant literature reviewed on financial development and private investment, we present a model for estimating private investment for Ghana. The main variable of interest is financial development. Real interest rate, trade openness, real exchange rate, public investment, and real GDP per capita are used as control variables. Thus, the relationship between financial development and private investment in Ghana is given as:

$$
P I_{t}=\varnothing_{0}+\varnothing_{1} F D_{t}+\varnothing_{2} R_{t}+\varnothing_{3} O P E N_{t}+\varnothing_{4} R E R_{t}+\varnothing_{5} P U I N V_{t}+\varnothing_{5} Y_{t}+\varepsilon_{t}
$$

where FD is a vector of financial development indicators and all other variables are as previously defined in Section 3.1. PI is private investment and $\varepsilon_{t}$ represents the error term. Except real GDP per capita, which is expressed in logarithm terms, all other variables are measured as a ratio of GDP. In the empirical estimation, the study re-specifies Equation (1) in a conditional error correction form within the ARDL framework. The conditional error correction model (ECM) to test long-run relationship is of the form:

$$
\Delta P I_{t}=\gamma+\sum_{i=1}^{r} \Delta P I_{t-i}+\sum_{i=0}^{r} \Phi_{m} \Delta X_{t-i}+\delta_{1} P I_{t-1}+\delta_{m} X_{t-1}+\mu_{t},
$$

where PI is as previously defined, $\mathrm{m}$ is the number of regressors, $X$ is a vector of observations of included explanatory variables in Equation (1), $\gamma$ is intercept, $\mu_{t}$ is the error term, $r$ is the optimal lag length, and $\Delta$ is a difference operator.

Generally speaking, econometric analysis of times series data begins with the verification of the stationarity or otherwise of the underlying series individually. The existence of a unit root in the series indicates non-stationarity in the series, hence the variables are not mean reverting. The implication is that shock to the unit root process is permanent unlike stationary series where shocks only have temporal effects. This paper adopted the traditional Augmented Dickey-Fuller (ADF), and Phillips-Perron unit root tests to examine the time series properties of each variable. Though unit root test is not a pre-requisite for the ARDL approach to cointegration, the absence of I(2) variable should be guaranteed to avoid spurious results. Following our identification of five indicators of financial development, we conduct five cointegration tests by alternating the FD indicators.

\section{Empirical Results and Discussion}

\subsection{Unit Root Test Results}

As indicated in the previous section, ADF, and Phillips-Perron unit root tests were used to determine the order of integration of the underlying variables. As evident in Table 1 with the exception of PI and R, which can be classified as $\mathrm{I}(0)$ variables, especially when the trend version is considered, all of the other variables achieved stationarity after their first differencing implying $\mathrm{I}(1)$ order of integration. Evidently, all the variables are integrated of either I(0) or I(1). The statistical implications are that the OLS estimator is likely to produce spurious results. It is for this reason that we employ the ARDL approach to take care of the mixture of stationary and non-stationarity problems in the regressors. 
Table 1. Unit root test results.

\begin{tabular}{|c|c|c|c|c|c|c|c|c|}
\hline \multirow{3}{*}{ Variables } & \multicolumn{4}{|c|}{ ADF } & \multicolumn{4}{|c|}{ PP } \\
\hline & \multicolumn{2}{|c|}{ Levels } & \multicolumn{2}{|c|}{ 1st Difference } & \multicolumn{2}{|c|}{ Levels } & \multicolumn{2}{|c|}{ 1st Difference } \\
\hline & $\mathrm{C}$ & CT & $\mathrm{C}$ & CT & $\mathrm{C}$ & CT & $\mathrm{C}$ & CT \\
\hline PI & -1.424 & $-3.705^{* *}$ & $-8.259^{* * *}$ & $-6.408^{* * *}$ & -1.143 & $-3.566^{* *}$ & $-11.225^{* * *}$ & $15.394^{* * *}$ \\
\hline PUINV & -1.590 & -1.598 & $-5.971^{* * *}$ & $-5.920 * * *$ & -1.590 & -1.598 & $-5.952 * * *$ & $-5.894 * * *$ \\
\hline OPEN & -0.825 & -2.154 & $-5.871^{* * *}$ & $-5.811^{* * *}$ & -0.831 & -2.201 & $-5.871^{* * *}$ & $-5.811^{* * *}$ \\
\hline Y & -0.326 & -1.261 & $-4.223^{* * *}$ & $-5.829 * * *$ & -0.810 & -0.390 & $-4.230 * * *$ & $-7.362^{* * *}$ \\
\hline RER & -1.508 & -2.820 & $-3.804^{* * *}$ & $-3.842^{* *}$ & -1.169 & -2.100 & $-3.608^{* * *}$ & $-3.587^{* *}$ \\
\hline $\mathrm{R}$ & $-2.613^{*}$ & $-4.769 * * *$ & $-7.834^{* * *}$ & 7.782 *** & $-4.390 * * *$ & $-4.873^{* * *}$ & $-13.322^{* * *}$ & $-13.296^{* * *}$ \\
\hline PSC & -0.020 & -1.830 & $-5.609 * * *$ & $-6.319 * * *$ & -0.097 & -2.154 & $-5.584^{* * *}$ & $-6.524^{* * *}$ \\
\hline $\mathrm{BM}$ & -1.088 & -1.688 & $-6.246^{* * *}$ & $-6.209 * * *$ & -1.209 & -1.820 & $-6.251^{* * *}$ & $6.209 * * *$ \\
\hline DMG & -0.160 & 2.046 & $-4.703^{* * *}$ & $-4.941^{* * *}$ & -0.506 & 1.685 & $-4.688^{* * *}$ & $-4.966^{* * *}$ \\
\hline FDG & -0.433 & -1.495 & $-5.897^{* * *}$ & $-6.033^{* * *}$ & -0.512 & -1.476 & $-5.863^{* * *}$ & $-6.044^{* * *}$ \\
\hline FDPCA & -0.350 & -1476 & $-6.015^{* * *}$ & $-6.215^{* * *}$ & -0.350 & -1.469 & $-5.999 * * *$ & $-6.213^{* * *}$ \\
\hline
\end{tabular}

$*, * *, * *$ denote rejection of the null hypothesis of the existence of unit root in the series at $10 \%, 5 \%$ and $1 \%$ respectively. $\mathrm{C}=$ constant, $\mathrm{CT}=$ constant and linear trend; $\mathrm{ADF}=$ Augmented Dickey-Fuller, $\mathrm{PP}=\mathrm{Philips}-\mathrm{Peron}$.

\subsection{ARDL Bounds Test and Long Run and Short Run Results}

In testing the long-run equilibrium relationship between private investment and financial development, the bounds test approach to cointegration procedure was implemented. We tested for a long-run equilibrium relationship between private investment and the independent variables, including an indicator for FD at a time. Interestingly, we found cointegration in all of the five models estimated. Table 2 reports the results from the ARDL bounds test.

Table 2. ARDL cointegration (bounds) test results.

\begin{tabular}{ccccccc}
\hline & Models & F-Statistic & K & \multicolumn{3}{c}{ Critical values } \\
\hline 1 & PI = f(PUINV, OPEN, Y, RER R, PSC) & 4.895 & 6 & $\%$ & $\mathrm{I}(0)$ & $\mathrm{I}(1)$ \\
2 & PI = f(PUINV, OPEN, Y, RER R, BM) & 5.027 & 6 & 10 & 2.12 & 3.23 \\
3 & PI = f(PUINV, OPEN, Y, RER R, DMG) & 3.534 & 6 & 5 & 2.45 & 3.61 \\
4 & PI = f(PUINV, OPEN, Y, RER R, FDG) & 4.809 & 6 & 1 & 3.15 & 4.43 \\
5 & PI = f(PUINV, OPEN, Y, RER R, FDPCA) & 4.090 & 6 & & & \\
\hline
\end{tabular}

$\mathrm{K}$ is the number of regressors. If the statistic lies between the bounds, the test is inconclusive. If it is above the upper bound, the null hypothesis of no level effect is rejected.

Evidence of a cointegration relationship between private investment and the explanatory variables presented in the models has been established at least at a $90 \%$ confidence level, and a linear combination of the variables will follow a stationary process, hence convergence to long-run equilibrium is feasible. Having established a cointegrating relationship between private investment and its driving forces, we advance to estimate the long-run equilibrium effects of the different FD indicators after controlling for some determinants of private investment. The long-run results are presented in Table 3.

In all of the models estimated, none of the proxy measures of financial development had a statistically significant coefficient. This suggests that financial development, regardless of how it is measured, has not had any effect on private investment in Ghana. More specifically, measuring financial development by private sector credit to GDP, broad money supply, deposit money bank assets to GDP, and financial system deposit to GDP, and the overall index had no impact on private investment in Ghana during the period 1970-2014. In most cases, credit provided to the private sector is expected to ease financing constraints, which increases private sector capital formation, and the results from Eshun et al. (2014) [23]; Ucan and Ozturk (2011) [38], and Asante (2000) [19] support this view. Similar to the findings here, Frimpong and Marbuah (2010) [22] found that credit to private sector has no significant effect on private investment. Our results are also consistent with Eshun et al. (2014) [23] if FD is measured by a broad money supply. 
Table 3. Long-run results.

\begin{tabular}{|c|c|c|c|c|c|}
\hline \multirow{2}{*}{ Variables } & \multicolumn{5}{|c|}{ Equation } \\
\hline & 1 & 2 & 3 & 4 & 5 \\
\hline PUINV & $\begin{array}{c}0.055 \\
(0.259)\end{array}$ & $\begin{array}{c}-0.274 \\
(0.223)\end{array}$ & $\begin{array}{c}-0.367 \\
(0.263)\end{array}$ & $\begin{array}{c}0.135 \\
(0.263)\end{array}$ & $\begin{array}{l}-0.165 \\
(0.193)\end{array}$ \\
\hline OPEN & $\begin{array}{c}0.166^{* * *} \\
(0.042)\end{array}$ & $\begin{array}{c}0.185^{* * *} \\
(0.037)\end{array}$ & $\begin{array}{c}0.216^{* * *} \\
(0.058)\end{array}$ & $\begin{array}{c}0.138^{* * *} \\
(0.037)\end{array}$ & $\begin{array}{c}0.184^{* * *} \\
(0.039)\end{array}$ \\
\hline $\mathrm{Y}$ & $\begin{array}{c}0.230^{* * *} \\
(0.050)\end{array}$ & $\begin{array}{c}0.173^{* * *} \\
(0.039)\end{array}$ & $\begin{array}{c}0.177^{* * *} \\
(0.040)\end{array}$ & $\begin{array}{c}0.191^{* * *} \\
(0.057)\end{array}$ & $\begin{array}{c}0.198 * * * \\
(0.045)\end{array}$ \\
\hline RER & $\begin{array}{l}-0.020 \\
(0.014)\end{array}$ & $\begin{array}{c}-0.012 \\
(0.011)\end{array}$ & $\begin{array}{c}0.015 \\
(0.014)\end{array}$ & $\begin{array}{c}-0.023 \\
(0.014)\end{array}$ & $\begin{array}{l}-0.020 \\
(0.012)\end{array}$ \\
\hline $\mathrm{R}$ & $\begin{array}{c}-0.007 \\
(0.023)\end{array}$ & $\begin{array}{c}0.027 \\
(0.029)\end{array}$ & $\begin{array}{c}0.011 \\
(0.025)\end{array}$ & $\begin{array}{l}-0.005 \\
(0.023)\end{array}$ & $\begin{array}{c}0.029 \\
(0.023) \\
\end{array}$ \\
\hline SC & $\begin{array}{c}-0.414 \\
(0.298)\end{array}$ & - & - & - & - \\
\hline $\mathrm{BM}$ & - & $\begin{array}{l}-0.229 \\
(0.139)\end{array}$ & - & - & - \\
\hline DMG & - & - & $\begin{array}{c}-0.286 \\
(0.171)\end{array}$ & - & - \\
\hline FDG & - & - & - & $\begin{array}{l}-0.046 \\
(0.236)\end{array}$ & - \\
\hline FDPCA & - & - & - & - & $\begin{array}{c}-0.008 \\
(0.006)\end{array}$ \\
\hline Constant & $\begin{array}{c}-1.385^{* * * *} \\
(-1.385)\end{array}$ & $\begin{array}{c}-0.994^{* * *} \\
(0.231)\end{array}$ & $\begin{array}{c}-1.048^{* * *} \\
(0.242)\end{array}$ & $\begin{array}{c}-1.163^{* * *} \\
(0.341)\end{array}$ & $\begin{array}{c}-1.209 * * * \\
(0.292)\end{array}$ \\
\hline
\end{tabular}

It is imperative to take a critical look at the controlled variables. Only two of the control variables were statistically significant in influencing private investment in Ghana during the period. Trade openness and per capita income consistently recorded significant positive effects. The coefficients ranged from 0.138 to 0.238 for trade openness and 0.173 and 0.230 for per capita income Thus, private investment increases by between $0.138 \%$ and $0.238 \%$ following a $1 \%$ increase in trade openness. The outcome of trade openness could be attributed to the availability of high quality and sophisticated (capital) inputs. Indeed, during this period, private investors had access to capital equipment and other sophisticated machines for production. The exposure of domestic investors to the international market also enhanced their activities. This does not seem to support Serven's (2002) [50] argument that liberalisation will hamper investment. The current findings contradict that of Frimpong and Marbuah (2010) [22]. Similarly, a 1\% increase in per capita income was associated with between $0.173 \%$ and $0.230 \%$ increase in private investment. This confirms the accelerator theory of investment reported in, for example, Eshun et al. (2014) [23], Frimpong and Marbuah (2010) [22] and Outtarra (2004) [6].

Regarding the short-run results (see Table 4), except for broad money supply, deposit money bank assets to GDP, and the overall index of financial development, the other indicators of financial development are not statistically significant. This suggests that only FD indictors such as BM, DMG and FDPCA influence private investment in the short run.

The diagnostic tests show that the models are well specified as they did not suffer from autocorrelation, heteroscedasticity, and functional form; and the residuals were normally distributed (see Table 5). Furthermore, all graphs for the "CUSUM and CUSUMQ" of the residuals (see Appendix) indicated that the models are well fitted. Similarly, the speed of adjustment to restore equilibrium following a disturbance were statistically significant at $1 \%$ level in all the models, with an average 
speed of adjustment ranging between $0.87 \%$ and $0.92 \%$. That is to say, adjustment to restore long-run equilibrium is reasonably high.

The behaviour of the control variables did not change much in the short run. Trade openness and per capita GDP remained robust. Real exchange rate was marginally significant in models 1 and 4 , suggesting that currency depreciation induces private investment in the short run. While the short-run results on real exchange rate are consistent, trade openness is inconsistent with the findings of Frimpong and Marbuah (2010) [22]. The rest of the variables were statistically insignificant in influencing private investment.

Table 4. Short-run results.

\begin{tabular}{|c|c|c|c|c|c|}
\hline \multirow{2}{*}{ Variables } & \multicolumn{5}{|c|}{ Equation } \\
\hline & 1 & 2 & 3 & 4 & 5 \\
\hline$\Delta$ PUINV & $\begin{array}{c}0.048 \\
(0.227)\end{array}$ & $\begin{array}{c}0.337 \\
(0.261)\end{array}$ & $\begin{array}{l}-0.298 \\
(0.203)\end{array}$ & $\begin{array}{c}0.120 \\
(0.236)\end{array}$ & $\begin{array}{c}0.498 \\
(0.310)\end{array}$ \\
\hline$\triangle \mathrm{OPEN}$ & $\begin{array}{c}0.145^{* * *} \\
(0.033)\end{array}$ & $\begin{array}{c}0.157^{* * * *} \\
(0.030)\end{array}$ & $\begin{array}{c}0.176^{* * * *} \\
(0.041)\end{array}$ & $\begin{array}{c}0.123^{* * *} \\
(0.032)\end{array}$ & $\begin{array}{c}0.169 * * * \\
(0.033)\end{array}$ \\
\hline$\Delta \mathrm{Y}$ & $\begin{array}{c}0.200^{* * *} \\
(0.049)\end{array}$ & $\begin{array}{c}0.147^{* * *} \\
(0.040)\end{array}$ & $\begin{array}{c}0.144^{* * * *} \\
(0.038)\end{array}$ & $\begin{array}{c}0.170^{* * * *} \\
(0.056)\end{array}$ & $\begin{array}{c}0.182 * * * \\
(0.046)\end{array}$ \\
\hline$\triangle \mathrm{RER}$ & $\begin{array}{l}-0.002 \\
(0.016)\end{array}$ & $\begin{array}{l}-0.010 \\
(0.009)\end{array}$ & $\begin{array}{l}-0.012 \\
(0.011)\end{array}$ & $\begin{array}{l}-0.005 \\
(0.018)\end{array}$ & $\begin{array}{l}-0.019 \\
(0.011)\end{array}$ \\
\hline$\Delta \mathrm{RER}(-1)$ & $\begin{array}{l}0.030 \text { * } \\
(0.017)\end{array}$ & - & - & $\begin{array}{l}0.031^{*} \\
(0.018)\end{array}$ & - \\
\hline$\Delta \mathrm{R}$ & $\begin{array}{l}-0.006 \\
(0.020)\end{array}$ & $\begin{array}{c}0.023 \\
(0.024)\end{array}$ & $\begin{array}{c}0.009 \\
(0.020)\end{array}$ & $\begin{array}{l}-0.004 \\
(0.021)\end{array}$ & $\begin{array}{c}0.026 \\
(0.022)\end{array}$ \\
\hline$\triangle \mathrm{PSC}$ & $\begin{array}{l}-0.360 \\
(0.247)\end{array}$ & - & - & - & - \\
\hline$\Delta \mathrm{BM}$ & - & $\begin{array}{c}-0.584^{* * *} \\
(0.169)\end{array}$ & - & - & - \\
\hline$\Delta \mathrm{DMG}$ & - & - & $\begin{array}{c}-0.232 * \\
(0.129)\end{array}$ & - & - \\
\hline$\Delta \mathrm{FDG}$ & - & - & - & $\begin{array}{l}-0.041 \\
(0.210)\end{array}$ & - \\
\hline$\triangle \mathrm{FDPCA}$ & - & - & - & - & $\begin{array}{c}-0.018 \text { ** } \\
(0.007)\end{array}$ \\
\hline ECMT-1 & $\begin{array}{c}-0.871^{* * * *} \\
(0.137)\end{array}$ & $\begin{array}{c}-0.850^{* * * *} \\
(0.124)\end{array}$ & $\begin{array}{c}-0.813^{* * *} \\
(0.135)\end{array}$ & $\begin{array}{c}-0.891 \text { *** } \\
(0.141)\end{array}$ & $\begin{array}{c}-0.919^{* * *} \\
(0.132)\end{array}$ \\
\hline
\end{tabular}

$*,{ }^{* *},{ }^{* * *}$ denote significance at $10 \%, 5 \%$ and $1^{*}$ level respectively. Standard errors in parenthesis. $\Delta$ is lag difference operator.

Table 5. Diagnostic test results.

\begin{tabular}{ccccc}
\hline Models & Autocorrelation $^{\mathbf{a}}$ & Heteroscedasticity $^{\mathbf{b}}$ & Normality $^{\mathbf{c}}$ & Functional Form $^{\mathbf{d}}$ \\
\hline \multirow{2}{*}{1} & 0.535 & 0.720 & 0.518 & 1.358 \\
& $(0.591)$ & $(0.687)$ & $(0.771)$ & $(0.252)$ \\
\hline \multirow{2}{*}{2} & 0.518 & 0.753 & 2.247 & 1.639 \\
& $(0.600)$ & $(0.659)$ & $(0.325)$ & $(0.209)$ \\
\hline \multirow{2}{*}{3} & 0.282 & 0.489 & 0.633 & 2.519 \\
& $(0.756)$ & $(0.836)$ & $(0.782)$ & $(0.121)$ \\
\hline \multirow{2}{*}{4} & 0.933 & 0.796 & 0.993 & 2.064 \\
& $(0.404)$ & $(0.623)$ & $(0.609)$ & $(0.161)$ \\
\hline \multirow{2}{*}{5} & 0.682 & 0.853 & 0.452 & 1.847 \\
& $(0.513)$ & $(0.574)$ & $(0.798)$ & $(0.183)$ \\
\hline
\end{tabular}

Note tests are based on: ${ }^{\text {a }}$ Breusch-Godfrey LM; ${ }^{\mathrm{b}}$ Breusch-Pagan-Godfrey; ${ }^{\mathrm{c}}$ Jarque-Bera; ${ }^{\mathrm{d}}$ Ramsey RESET. Probabilities in parentheses. 


\section{Conclusions}

The impact of financial development on private investment remains an elusive empirical matter in economic literature. This paper sought to investigate the long- and short-run impact of financial development on private investment in Ghana by using five proxy measures of financial development, namely, private sector credit to GDP, broad money supply to GDP, deposit money bank assets to GDP, financial system deposit to GDP, and an index of these four indicators constructed by principal component analysis. The ARDL bounds test approach to cointegration was used for the estimation. The results suggest that the impact of FD on private investment is susceptible to the type of FD indicator used, in the short run but not in the long run. For example, in the long run, all indicators of financial development: private sector credit, broad money supply to GDP, deposit money banks' assets to GDP, and financial system deposits exerted no significant influence on private investment. In the short run, however, broad money supply and index of all FD indicators had an important effect on private investment. The findings are very important to aid in understanding the conflicting results in the literature, as many studies rely on a single FD indicator and are therefore unable to identify FD indicators that can propel private sector investment. The findings serve as a caution for policy makers regarding the choice of financial development measure(s) as policy instrument(s) in the design and implementation of investment policies.

Author Contributions: All authors contributed equally to the paper.

Conflicts of Interest: The authors declare no conflict of interest.

\section{Appendix}
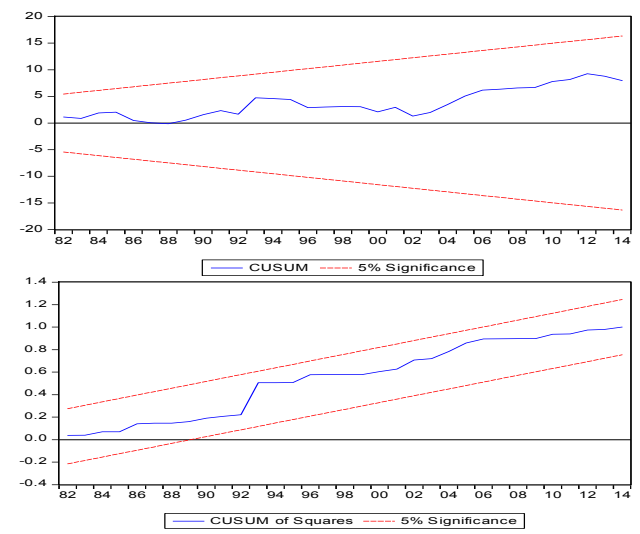

Figure A1. CUSUM and CUSUMQ results for Model 1: PI = f(PUINV, OPEN, Y, RER R, PSC).

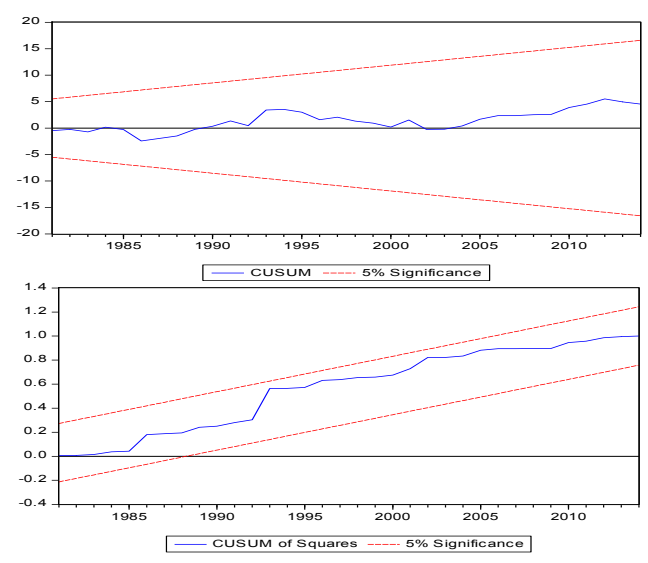

Figure A2. CUSUM and CUSUMQ results for Model 2: PI = f(PUINV, OPEN, Y, RER R). 

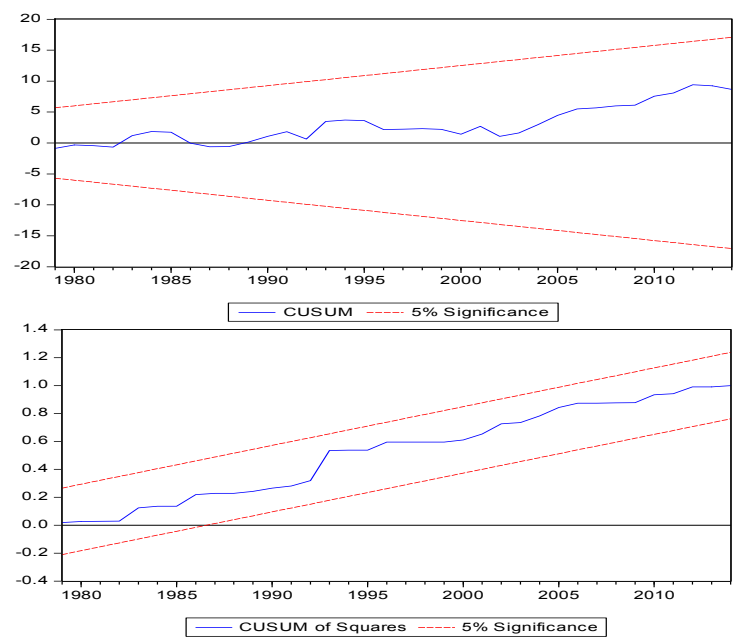

Figure A3. CUSUM and CUSUMQ results for Model 3: PI = f(PUINV, OPEN, Y, RER R, DMG).
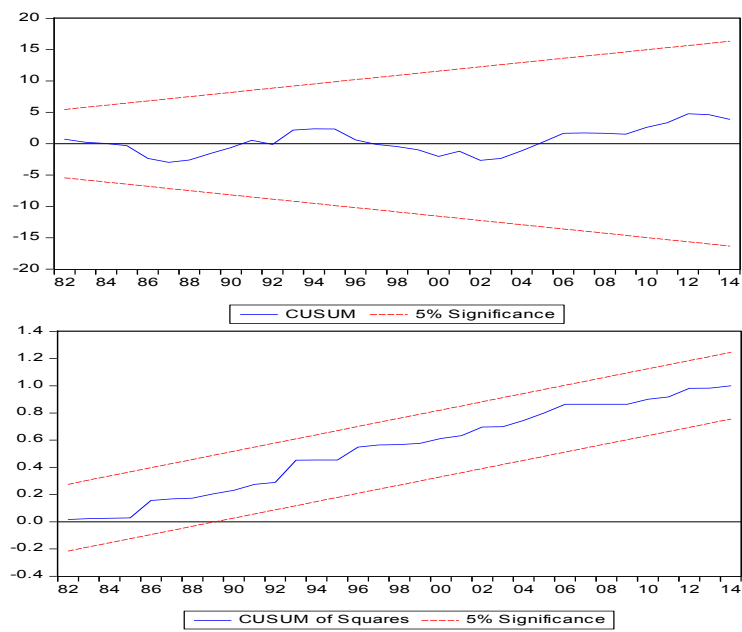

Figure A4. CUSUM and CUSUMQ results for Model 4: PI = f(PUINV, OPEN, Y, RER R, FDG).
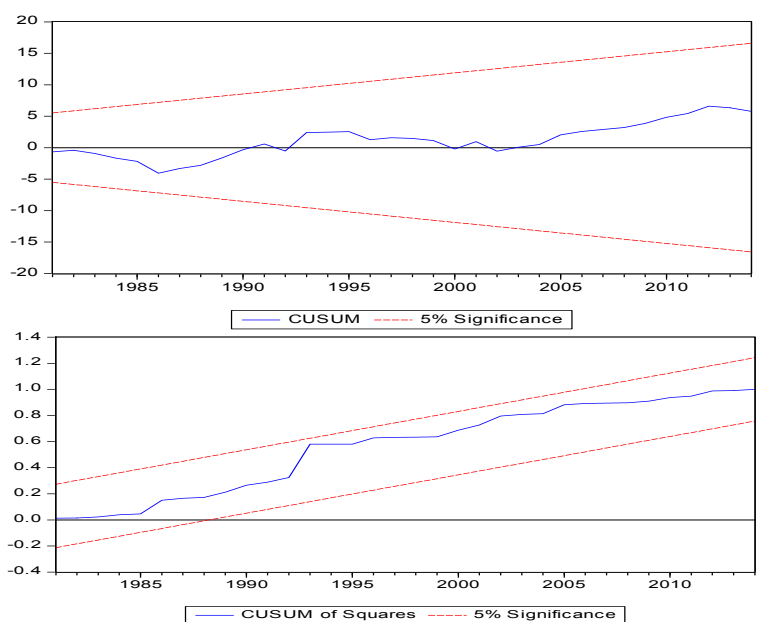

Figure A5. CUSUM and CUSUMQ results for Model 5: PI = f(PUINV, OPEN, Y, RER R, FDPCA $)$. 


\section{References}

1. Khan, M.S.; Reinhart, C.M. Private Investment and Economic Growth in Developing Countries. World Dev. 1990, 18, 1. [CrossRef]

2. Hoeffler, A. Openness, Investment and Growth. J. Afr. Econ. 2002, 10, 470-497. [CrossRef]

3. Frimpong, S.; Adam, A.M. Does financial Sector Development cause investment and growth? Empirical analysis of the case of Ghana. J. Bus. Enterp. Dev. 2010, 2, 67-84.

4. Coutinho, R.; Gallo, G. Do Public and Private Investment Stand in Each Other's Way. World Development Report background paper, mimeo. World Bank Washington, D.C. Cross-Country Empirical Investigation. Appl. Econ. 1991, 32, 1819-1829.

5. Serven, L.; Solimano, A. Private Investment and Macroeconomic Adjustment: Theory, Country Experience and Policy Implications; World Bank: Washington, DC, USA, 1990.

6. Ouattara, B. Modelling the Long Run Determinants of Private Investment in Senegal; University of Nottingham: Nottingham, UK, 2004.

7. Huang, Y. Private Investment and Financial Development in a Globalized World; Department of Land Economy, University of Cambridge: Cambridge, UK, 2010.

8. Mckinnon, R. Money and Capital in Economic Development; Brookings Institution: Washington, DC, USA, 1973.

9. Shaw, E. Financial Deepening in Economic Development; Oxford University Press: New York, NY, USA, 1973.

10. Singh, A. Financial Liberalization, Stock Markets and Economic Development. Econ. J. 1997, 107, 77-182. [CrossRef]

11. Van, W. Interest Rate Management in LDC's. J. Mon. Econ. 1983, 12, 433-452.

12. Taylor, L. Structuralist Macroeconomics: Applicable Models for the Third World; Basic Books, Inc.: New York, NY, USA, 1983.

13. Lensink, R. The Allocative Efficiency of the Formal versus the Informal Financial Sector. Appl. Econ. Lett. 1996, 3, 163-165. [CrossRef]

14. Burkett, P.; Dutt, A.K. Interest Rate Policy, Effective Demand and Growth in LDCs. Int. Rev. Appl. Econ. 1991, 5, 127-154.

15. Aryeetey, E.; Nissanke, M.; Steel, W.F. Intervention and liberalization: Changing policies and performance in the financial sector. In Economic Reforms in Ghana: The Miracle and the Mirage; Aryeetey, E., Harrigane, J., Nissanke, M., Eds.; James Currey and Woeli Publishers: Oxford, UK, 2000.

16. Bawumia, M. Monetary Policy and Financial Sector Reform in Africa: Ghana's Experience; Combert Impressions Ghana Ltd.: Accra, Ghana, 2010.

17. Asare, E. The impact of financial liberalization on private investment in Ghana. Int. J. Bus. Financ. Res. 2013, 7,77-90.

18. Naa-Idar, F.; Ayentimi, D.T.; Frimpong, M.J. A Time Series Analysis of Determinants of Private Investment in Ghana (1960-2010). J. Econ. Sustain. Dev. 2012, 3, 13.

19. Asante, Y. Determinants of Private Investment Behaviour; African Economic Research Consortium (AERC): Nairobi, Kenya, 2000.

20. Ibrahim, S.B. Modelling the Determinants of Private Investment in Ghana. Afr. Financ. J. 2000, 2, 15-39.

21. Akpalu, W. Modelling Private Investment in Ghana: An Empirical Time Series Econometrics Investigation (1970-1994). Oguaa J. Soc. Sci. 2002, 4, 186-194.

22. Frimpong, J.M.; Marbuah, G. The Determinants of Private Sector Investment in Ghana: An ARDL Approach. Eur. J. Soc. Sci. 2010, 15, 2.

23. Eshun, M.E.; Adu, G.; Buabeng, E. Financial Determinants of Private Investment in Ghana. Int. J. Financ. Econ. 2014, 3, 25-40.

24. Keynes, J.M. The General Theory Employment, Interest and Money; Macmillan: London, UK, 1936.

25. Tobin, J. A General Equilibrium Approach to Monetary Theory. J. Mon. Cred. Bank. 1969, 1, 15-29. [CrossRef]

26. Jorgenson, D.W. Econometric Studies of Investment Behaviour: A Survey. J. Econ. Lit. 1971, 9, 1111-1147.

27. Pindyck, R. Irreversibility, Uncertainty and Investment. J. Econ. Lit. 1991, 29, 1110-1152.

28. Dixit, A.; Pindyck, R. Investment under Uncertainty; Princeton University Press: Princeton, NJ, USA, 1994.

29. World Economic Forum (WEF). The Financial Development Report, 2012; World Economic Forum USA Inc.: New York, NY, USA, 2012. 
30. Greenwood, J.; Jovanovich, B. Financial Development, Growth, and the Distribution of Income. J. Pol. Econ. 1990, 98, 1076-1107. [CrossRef]

31. Fowowe, B. Financial Sector Reforms and Private Investment in Sub-Saharan African Countries. J. Econ. Dev. 2011, 36, 3 .

32. Diamond, D.W. Financial intermediation and delegated monitoring. Rev. Econ. Stud. 1984, 51, $393-414$. [CrossRef]

33. Diamond, D.W.; Dybvig, P. Bank runs, deposit insurance and liquidity. J. Pol. Econ. 1983, 91, 401-419. [CrossRef]

34. Bencivenga, V.R.; Smith, B.D. Financial intermediation and endogenous growth. Rev. Econ. Stud. 1991, 58, 195-209. [CrossRef]

35. Greenwood, J.; Smith, B.D. Financial markets in development, and the development of financial markets. J. Econ. Dyn. Control 1997, 21, 145-181. [CrossRef]

36. Mbanga, N.G. External debt and private investment in Cameroon. Afr. J. Econ. Pol. 2002, 9, 109-125. [CrossRef]

37. Ndikumana, L. Financial Determinants of Domestic Investment in Sub-Saharan Africa: Evidence from Panel Data. World Dev. 2000, 28, 381-400. [CrossRef]

38. Ucan, O.; Ozturk, O. Financial Determinants of Investment for Turkey. J. Econ. Soc. Stud. 2011, 1, 83-109. [CrossRef]

39. Oshikoya, T.W. Interest Rate Liberalization, Savings, Investment and Growth: The Case of Kenya. Sav. Dev. 1992, 16, 305-320.

40. Ang, J.B. Private Investment and Financial Sector Policies in India and Malaysia. World Dev. 2009, 37, 1261-1273. [CrossRef]

41. Khan, M.A. Financial Development and Economic Growth in Pakistan: Evidence Based on Autoregressive Distributed Lag (ARDL) Approach. South Asia Econ. J. 2008, 9, 375-391. [CrossRef]

42. King, R.G.; Levine, R. Finance, Entrepreneurship and Growth. J. Mon. Econ. 1993, 32, 30-71. [CrossRef]

43. Moshi, H.P.B.; Kilindo, A.A.L. The Impact of Government Policy on Macroeconomic Variables: A Case Study of Private Investment in Tanzania; African Economic Research Consortium: Nairobi, Kenya, 1999.

44. Levine, R.; Loayza, N.; Beck, T. Financial Intermediation and Growth: Causality and Causes. J. Mon. Econ. 2000, 46, 31-77. [CrossRef]

45. Lenka, S.K. Measuring financial development in India: A PCA approach. Theor. Appl. Econ. 2015, 1, 187-198.

46. Demetriades, P.O.; Hussein, K.A. Does financial development cause economic growth? Time-series evidence from 16 countries. J. Dev. Econ. 1996, 51, 387-411. [CrossRef]

47. King, R.G.; Levine, R. Finance and Growth: Schumpeter Might be Right. Q. J. Econ. 1993, 108, $717-737$. [CrossRef]

48. Fry, M.J. In Favour of Financial Liberalization. Econ. J. 1997, 107, 754-770. [CrossRef]

49. World Bank. World Development Report 1989; Oxford University Press: New York, NY, USA, 1989.

50. Serven, L. Real Exchange Rate Uncertainty and Private Investment in Developing Countries; Domestic Finance Working Paper 2823; World Bank: Washington, DC, USA, 2002.

(C) 2016 by the authors; licensee MDPI, Basel, Switzerland. This article is an open access article distributed under the terms and conditions of the Creative Commons Attribution (CC-BY) license (http://creativecommons.org/licenses/by/4.0/). 